\title{
Andrzej Suliborski
}

\section{Koncepcja regionalna w twórczości naukowej Ludwika Straszewicza}

Artykuł jest próbą analizy prac naukowych z zakresu geografii regionalnej prof. dr Ludwika Straszewicza, jednego z najwybitniejszych geografów społeczno-ekonomicznych okresu powojennego, którego twórczość naukowa przypadała na lata 1959-1987 (Liszewski [red.] 2009). Możemy w niej wyróżnić co najmniej trzy kierunki badawcze związane z geografią miast, przemysłu oraz geografią regionalną. $W$ obszernym dorobku naukowym profesora do prac regionalnych można zaliczyć jednoznacznie tylko te książki czy artykuły, które odnoszą się do poszczególnych krajów i ich grup - Francji, Włoch, krajów socjalistycznych (np. Straszewicz 1972a; Straszewicz 1977; Straszewicz 1974), mniejszych regionów administracyjnych - monografie województw opolskiego i łódzkiego (Straszewicz 1956; Straszewicz 1967) lub atlasy gospodarcze województw łódzkiego, opolskiego i bydgoskiego (Straszewicz 1965a; Straszewicz 1962; Straszewicz 1973). Należy jednak zwrócić uwagę, że w pracach zaliczanych do innych subdyscyplin geograficznych (np. geografii miast i geografii przemysłu), profesor bardzo często wykorzystywał metodę regionalną przez jednoznaczne osadzenie problemu badawczego w wyznaczonych ramach przestrzennych (np. jednostkach administracyjnych, miastach, aglomeracji, strefie podmiejskiej, okręgu przemysłowym, itp.) oraz sposób prezentacji zjawisk i procesów lub ich wzajemnych uwarunkowań. Podejście regionalne dominowało więc $\mathrm{w}$ twórczości naukowej profesora bez względu na problematykę badawcza, którą podejmował, co wiązało się ściśle z dominującym w jego pokoleniu klasycznym modelem uprawiania geografii.

Celem rozważań prowadzonych $\mathrm{w}$ artykule jest próba określenia charakteru geografii regionalnej w ujęciu profesora Ludwika Straszewicza na podstawie analizy prac naukowych z tego zakresu, tym łatwiejsza, że byłem jego uczniem i mogłem w trakcie licznych rozmów prywatnych i oficjalnych spotkań naukowych poznać jego poglądy dotyczące naukowego sensu geografii. 
Refleksja nad pracami, które możemy zaliczyć do nurtu regionalnego, służąca zdefiniowaniu charakteru geografii regionalnej uprawianej przez profesora wymaga rozpatrzenia trzech zagadnień:

- zarysowania charakteru geografii regionalnej, jej sensów i znaczeń w geografii w kontekście ujęć regionalnych profesora Ludwika Straszewicza, co nie jest zadaniem łatwym ze względu na jej słabe i stale kwestionowane podstawy teoretyczno-metodologiczne;

- wyjaśnienia uwarunkowań twórczości profesora wynikających z jego wykształcenia, rozwoju naukowego oraz czasu, w jakim przyszło mu uprawiać geografię;

- sprecyzowania istoty i cech koncepcji regionalnej, realizowanej przez profesora Ludwika Straszewicza.

\section{Geografia regionalna - koncepcja regionalna w geografii}

W procesie rozwoju myśli geograficznej koncepcja regionalna stanowiła jeden $z$ najważniejszych nurtów myślowych i trudno przecenić jej znaczenie dla współczesnej geografii (Suliborski 2003, 2006). Genezy tej koncepcji możemy upatrywać już w starożytności, u samych początków

120 geografii, która powstawała jako dziedzina wiedzy prowadząca swoje badania $\mathrm{w}$ dwóch ujęciach przestrzennych, z jednej strony zajmująca się zjawiskami i procesami (przyrodniczymi), odnoszącymi się do Ziemi jako całości (Erastotenes), z drugiej powołana do opisów określonych fragmentów Ziemi - ekumeny (Strabon). Jednoznacznie tę odmienność interpretacyjną geografii wyraził po raz pierwszy Ptolemeusz, odróżniając badania odnoszące się do poszczególnych fragmentów Ziemi nazywając je chorografia, od badań opisujących zasady i prawidłowości zjawisk dotyczących całej Ziemi, którymi miała zajmować się geografia (Nowakowski 1934). Później, zarówno jedną jak i drugą dziedzinę, określono jedną nazwą geografii. Podział Ptolemeusza był pierwszą próbą rozróżnienia w geografii problematyki poszczególnych obszarów od zagadnień traktujących o sprawach ogólnych Ziemi. Za sprawą Vareniusa (XVII w.) i klasyków geografii naukowej podział ten przetrwał do dzisiaj pod postacią geografii ogólnej (powszechnej) i geografii szczegółowej. Obie te geografie, w swoim rozwoju, przyjęły inne skale odniesienia i przedmioty swoich badań. W konsekwencji miały one różne założenia i cele procesu poznania, co wymagało przyjęcia odmiennych podstaw filozoficznych i teoretyczno-metodologicznych. Dla pierwszej najważniejsze było wyjaśnienie zjawisk i procesów fizykochemicznych, zachodzących w środowisku, dla drugiej - wyjaśnienie bytowania człowieka w określonym miejscu, charakteryzującym się pewnymi specyficznymi cechami środowiska przyrodniczego 
i uwarunkowaniami kulturowymi, powstałymi w długim procesie tworzenia i trwania. Immanentną zatem cechą geografii, od początku jej powstania jako nauki, było dualne patrzenie na otaczającą nas rzeczywistość ziemską.

W. Nałkowski podaje następujące rozróżnienie geografii ogólnej i szczegółowej: „W geografii ogólnej rozpatrujemy zjawiska ziemskie, dzielac je na kategorie (grupy) bąź według ich podobieństwa zewnętrznego [...] - bądź według ich podobieństwa wewnętrznego - pokrewieństwa, genezy (pochodzenia) [...]. Następnie rozpatrujemy każda taka kategorię w jej występowaniu, rozkładzie na całej ziemi. W geografii zaś szczegółowej dzielimy ziemię na pewne naturalne obszary-kraje, krainy, to jest pewne indywidualności geograficzne, które posiadaja pewne charakterystyczne cechy, różniace je od obszarów sasiednich" (za: Nowakowski 1934: 94). Geografia szczegółowa - odnosząca się do fragmentów Ziemi, regionów, przeistoczyła się w geografię regionalną, dla której oczywistym przedmiotem badania sa, jak mówił Nałkowski „naturalne obszary - kraje, krainy [...], indywidualności geograficzne". Ritterowi z kolei zawdzięczamy koncepcję badania nie krajów, a mniejszych obszarów - regionów, na które podzielił on kontynenty w swoim epokowym dziele Erdkunde. Ritteriańska koncepcja badania regionów stworzyła w geografii fundamentalną dla jej rozwoju kategorię pojęciowa, jaką jest region. Koncepcja regionalna przyczyniła się do wielkiego rozwoju geografii jako nauki i dziedziny praktycznej, ale zapoczątkowała też wielką dyskusję o naukowym sensie pojęcia region. Dyskusja ta dotyczy, przede wszystkim, ontologicznej i epistemologicznej istoty regionu geograficznego i trwa do dnia dzisiejszego, a geografowie nie mają nadal jednoznacznego poglądu na to, czym jest region geograficzny (Suliborski 2006).

Geografia regionalna była więc jedną z dwóch podstawowych idei geografii jako dziedziny wiedzy o zróżnicowaniu przestrzennym Ziemi. Geografia regionalna bada przestrzeń rzeczywistą (Kostrowicki 1997) lub realną (Chojnicki 1999) w podmiotowych kategoriach tej rzeczywistości, którymi są: obszar, region, struktura, system. Wyróżnikiem geografii regionalnej jest kompleksowe badanie tych wyodrębnionych obszarów przestrzeni geograficznej, która stanowi syntezę przestrzeni rzeczywistej (ziemskiej), zarówno w ujęciu obiektywistycznym, jak i subiektywistycznym, tak, jak gdyby stanowiły one pewne całości (Kostrowicki 1997).

Istotą geografii regionalnej jest holistyczna interpretacja konkretnego obszaru, miejsca, regionu w poszukiwaniu jego odmienności, wypływającej z różnego typu relacji wiążących o charakterze funkcjonalnym, przyczynowo-skutkowym i koegzystencjalnym, które czynią go mniej lub bardziej odrębnym w stosunku do otoczenia i przestrzennego sąsiedztwa.

Zadaniem geografii regionalnej jest odkrywanie pewnej indywidualności i odrębności jednych obszarów wobec innych, która stanowi efekt 
różnorodności zjawisk występujących na Ziemi. Poszukuje ona podstaw odmienności obszarów, która wynika z samej ich treści przyrodniczej i społecznej oraz z występujących relacji między elementami tworzącymi te treści. Naczelne idee geografii regionalnej (koncepcji regionalnej) zadecydowały o tym, że była ona i jest postrzegana przede wszystkim jako nauka dostarczająca zintegrowanej wiedzy o różnych obszarach Ziemi.

Podsumowując, można z całym przekonaniem stwierdzić, że od początku swojego istnienia geografia postrzegana była jako nauka regionalna, bez względu na to, jak byśmy ją rozumieli i stanowiła podstawowy sens badań geograficznych. Jej specyfiką było kompleksowe ujęcie zjawisk i procesów występujących w konkretnych miejscach i obszarach na Ziemi opisanych w sposób syntetyczny, tzn. z właściwą dla tej nauki selekcją faktów i procesów, wedle ich znaczenia dla tych obszarów - ich cech fizycznych, ludzi żyjących oraz powstałej kultury.

Profesor Ludwik Straszewicz niemal we wszystkich swoich pracach realizował ideę geografii postrzeganej jako nauka regionalna poprzez wykorzystywanie w swojej twórczości naukowej metody regionalnej, której nadał specyficzny sens. Metodę tę wykorzystywał szczególnie w pracach, które odnosiły się do konkretnych regionów, najczęściej wyznaczonych formalnymi granicami administracyjnymi lub historycznymi, a także $\mathrm{z}$ dużym powodzeniem stosował $\mathrm{w}$ tych artykułach, które zajmowały się istotnymi problemami specyficznymi dla pewnych obszarów czy stref, wywołanymi procesami społeczno-demograficznymi, gospodarczymi lub urbanizacją.

\section{Uwarunkowania naukowych zainteresowań regionalnych prof. Ludwika Straszewicza}

Działalność naukowa profesora Ludwika Straszewicza, twórcy łódzkiej szkoły geografii społeczno-ekonomicznej, wychowawcy kilku pokoleń geografów (magistrów, doktorów, doktorów habilitowanych i profesorów), kierownika Katedry Geografii Ekonomicznej (od 1957 do 1973), dyrektora Instytutu Geografii (1973-1975) oraz założyciela i pierwszego dyrektora Instytutu Geografii Społeczno-Ekonomicznej i Organizacji Przestrzeni na Uniwersytecie Łódzkim (od 1981 do przejścia na emeryturę w 1987), składa się z bardzo wielu publikacji książkowych i artykułów naukowych (łącznie liczy ponad 250 pozycji), zróżnicowanych tematycznie i przedmiotowo.

Wśród tego bogatego dorobku naukowego znaczną część stanowią prace, które zaliczyć można do tradycyjnie rozumianej geografii regionalnej. 
U podstaw tego nurtu zainteresowań profesora leżało, jak się wydaje wiele przyczyn, których nie sposób wymienić, a tym bardziej omówić. Stąd skupię się tylko na kilku czynnikach, w moim przekonaniu mających ważny wpływ na charakter jego prac i ukształtowanie swoistej dla tego autora koncepcji ujęcia regionalnego. Do czynników tych zaliczam: osobiste przymioty umysłu i ducha, rodzaj wykształcenia, pracę zawodowa, charakter promotora pracy doktorskiej, czas społeczno-polityczny, na który przypadała jego kariera akademicka oraz zmiany konceptualno-organizacyjne, jakie dokonały się w geografii polskiej.

Profesor Ludwik Straszewicz uzyskał bardzo solidne wykształcenie, które rozpoczął przed wojną w prestiżowej uczelni, Wyższej Szkole Handlowej w Warszawie, i zakończył po wojnie, uzyskując w 1945 r. stopień magistra ekonomii. Bardzo dobre wykształcenie ekonomiczne dało mu świetną znajomość funkcjonowania mechanizmów ekonomicznych, kształtujących gospodarkę państw, a w ich obrębie poszczególnych regionów. Rodzaj wykształcenia umożliwił mu podjęcie pracy w biurze regionalnym planowania przestrzennego, a później gospodarczego we Wrocławiu. W tym czasie rozpoczął także pracę jako starszy asystent na kierunku geograficznym Uniwersytetu Wrocławskiego. Działalność zawodowa w biurze planowania oraz zainteresowanie badaniami naukowymi, a także osoba przyszłego promotora profesora Józefa Wąsowicza zdecydowały o wyborze tematu pracy doktorskiej (Równina Wrocławska i jej znaczenie dla Polskiego Gospodarstwa Narodowego), którą obronił w 1949 r. jako pierwszy po wojnie geograf na Uniwersytecie Wrocławskim. Praca doktorska była wielkim doświadczeniem w zakresie studiów regionalnych i wypracowaniem metody badania związków cech obszaru fizycznego z jego eksploracją gospodarczą. Wydaje się, że zdobyte wówczas doświadczenie badawcze, a także działalność zawodowa w planowaniu regionalnym odcisnęły silne piętno na publikowanych później pracach profesora z zakresu geografii regionalnej.

Niewatpliwie na zainteresowania profesora L. Straszewicza problematyką regionalną miały również wpływ osobowość i zainteresowania naukowe profesora J. Wąsowicza, promotora pracy doktorskiej. Profesor Wąsowicz był kartografem, ale badawczo zajmował się antropogeografią oraz pasjonował się wyprawami i odkryciami geograficznymi. Być może zaszczepił on swojemu uczniowi zarówno chęć poznania różnych regionów świata z autopsji i ich opisania geograficznego, jak i wykorzystanie metody kartograficznej w syntezach regionalnych, które profesor L. Straszewicz stworzył później w postaci atlasów gospodarczych województw, stając się ich prekursorem i redaktorem (Straszewicz 1962a; Straszewicz 1967; Straszewicz 1973).

Wydaje się również, że na charakter prac regionalnych profesora L. Straszewicza, skoncentrowanych przede wszystkim na wątkach ekonomiczno- 
-historycznych i ludnościowych, miało pewien wpływ nieukończenie studiów geograficznych i związana $\mathrm{z}$ tym ograniczona znajomość klasycznych podstaw filozoficznych tej nauki. Z faktem tym wiązał się także brak w okresie studiów mistrzów geografów, na których mógł się wzorować, i z którymi się utożsamiał. Kontakt z profesorem J. Wąsowiczem miał dopiero jako wykształcony ekonomista podczas pisania pracy doktorskiej i w trakcie pracy na uczelni. Był to okres dość krótki, ponieważ już w 1952 r. profesor L. Straszewicz przeniósł się do Łodzi, organizując Pracownię Planów Regionalnych, którą kierował do 1956 r. W tym też roku został zatrudniony na Uniwersytecie Łódzkim jako zastępca profesora, docent, od 1964 profesor nadzwyczajny, a od 1975 zwyczajny.

Konsekwencją wykształcenia oraz kariery zawodowej profesora było skierowanie jego zainteresowań naukowych na problematykę geograficzno-ekonomiczną oraz studia regionalne, w których miał doświadczenie praktyczne. Pierwszym krokiem w tym kierunku była jego praca doktorska, w której próbował określić znaczenie praktyczne regionu (Równina Wrocławska) dla gospodarki Polski. W swoich pracach badawczych unikał odwoływania się do istniejących w literaturze geograficznej koncepcji teoretycznych, w których poruszał się umiarkowanie, natomiast kładł silny nacisk na stronę dokumentacyjną (faktograficzną) oraz własną intu-

124 icję. Pewnym wyjątkiem były prace dotyczące strefy podmiejskiej miast, w których podjął wątki pojęciowo-definicyjne związane z mechanizmami jej tworzenia (Straszewicz 1954; Straszewicz 1955; Straszewicz 1980b). Profesor stał na stanowisku, że geografia jest nauką prosta, przede wszystkim dokumentującą zjawiska i procesy zachodzące na Ziemi, której podstawowym zadaniem jest wspomaganie praktyki społeczno-gospodarczej. O jego stanowisku i poglądach na temat geografii świadczą nie tylko prace badawcze, lecz także ciągła współpraca z instytucjami gospodarczymi, wykonywanie na ich rzecz licznych ekspertyz i studiów badawczych (np. studia urbanistyczne miast), a w okresie późniejszym zaangażowanie się w tworzenie nowej subdyscypliny - geografii stosowanej.

Profesor Ludwik Straszewicz był silnie związany z miastem, gdzie mieszkał od urodzenia aż do śmierci. To miejskie pochodzenie sprawiło, że jego zainteresowania naukowe równie mocno związały się z miastem, które badał od strony historyczno-genetycznej, urbanistycznej, gospodarczej oraz funkcjonalnej, stając się niewątpliwym znawcą tej problematyki. Miasto jako przedmiot badań umożliwiało mu całkowite niemal abstrahowanie od analiz środowiska przyrodniczego, a skupianie się na procesach ekonomicznych, w tym przede wszystkim działalności przemysłowej, która wówczas decydowała o rynku pracy i zamożności mieszkańców.

Należy tutaj podkreślić, że jego geografia miast, z wyjątkiem kilku artykułów specjalistycznych, była bardzo silnie wpisana w regionalną kon- 
cepcję uprawiania geografii (Straszewicz 1963; Straszewicz 1965a; Straszewicz 1966; Straszewicz 1969a i b; Straszewicz 1972b).

Profesor rozwijał się jako geograf po wojnie, a początki jego kariery naukowej przypadają na czas bardzo burzliwych zmian społeczno-politycznych, w wyniku których dokonywała się przebudowa struktury i organizacji społeczeństwa oraz normalnej gospodarki rynkowej na wymuszoną przez ZSSR tzw. gospodarkę socjalistyczną. Zmiany te obejmowały również organizację nauki oraz przebudowę jej podstaw filozoficznych z pluralistycznych na jedynie obowiązującą filozofię marksistowska, wspierającą ideologię nowego systemu władzy. Proces tych zmian objął również polską geografię, która w okresie przedwojennym i pierwszych lat powojennych stanowiła jeszcze pewną kontynuację klasycznej myśli geograficznej, ukształtowanej przez Humboldta i Rittera, a później Ratzla i Vidala de la Blache'a. Zmiana podstaw filozoficznych, a tym samym zmiana paradygmatu badawczego nastąpiła $\mathrm{w}$ polskiej geografii $\mathrm{w}$ latach 50. Zostały one usankcjonowane sformułowaniem nowych zasad uprawiania geografii, zwłaszcza antropogeografii, która wzorem radzieckim została zmieniona na geografię ekonomiczną oraz uprawiana $\mathrm{w}$ postaci wyspecjalizowanych subdyscyplin, służących przede wszystkim szybkiemu rozwojowi poszczególnych gałęzi i działów gospodarki narodowej. Z dawnej antropogeografii zginął jeden z podstawowych jej przedmiotów badań - człowiek, mieszkańcy, społeczności - który zastąpiono geografią ludności, traktującą człowieka w kategorii nierównomiernie rozmieszczonego w przestrzeni geograficznej bytu biologicznego i ekonomicznego (siła robocza) - swego rodzaju zasobu (geografia ekonomiczna). Konferencja w Osiecznej w 1953 r. stała się przełomowa dla przebudowy dotychczasowego modelu geografii z dyscypliny kompleksowo-syntetycznej na zbiór wyspecjalizowanych nauk geograficznych o charakterze analitycznym, opierających się na marksistowskiej filozofii poznania i pozytywistycznym wzorcu uprawiania nauki. Wówczas to zapoczątkowany został proces powolnego rozmywania się geografii $\mathrm{w}$ dyscyplinach pokrewnych (np. geografii rolnictwa w naukach rolniczych, geografii przemysłu $w$ ekonomice przemysłu, geomorfologii w geologii itp.), prowadząc nieuchronnie do utraty jej tożsamości.

Był to okres, w którym podważone zostały również podstawy teoretyczne geografii szczegółowej (regionalnej) - drugiego, obok geografii ogólnej, członu geografii. Specjalistyczny rozwój nauk geograficznych zakwestionował implicite naczelną ideę badań geograficznych, jaką było kompleksowe ujęcie, polegające na równoczesnym traktowaniu zdarzeń i procesów w ich wzajemnych związkach i uwarunkowaniach, wymagające od geografa tego, co Kant nazywał „synopsją”, W. Pol „syntezą ducha”, a Nałkowski „,zmysłem geograficznym” (Wilczyński 1996). Uznanie straciły 
opracowania o charakterze regionalnych monografii geograficznych, które z definicji powinny przedstawiać pełnię aktualnej wiedzy dotyczącą określonych miejsc (regionów), przedstawioną w sposób rozumiejący sens zjawisk i procesów zachodzących w opisywanym i interpretowanym miejscu, a nie w formie encyklopedycznej, czyli stanowić geograficzną syntezę miejsca. Na skutek zmian dokonanych w geografii powojennej, monografie regionalne przyjęły nową formę narracji i przestały pełnić funkcję geograficznych syntez, straciły swój walor naukowości a w konsekwencji przestały być podstawą do nadawania stopni naukowych.

Profesor Ludwik Straszewicz niewątpliwie był pod wpływem zmian dokonujących się w polskiej geografii, ale podchodził do nich bardzo krytycznie i zarazem pragmatycznie. Ideologiczne uwarunkowania organizacji życia, a także ich wpływ na sposób uprawiania nauki były głęboko niezgodne z wyznawanym przez profesora światopoglądem. Dlatego też, będąc wierny swojemu wykształceniu i doświadczeniu zawodowemu w gospodarce regionalnej, przeciwstawiał się rewolucji ilościowej, jaką przeżywała wówczas geografia i jej odchodzeniu od klasyki badań geograficznych, którymi były studia regionalne i cała geografia regionalna, czemu dawał wyraz $\mathrm{w}$ swoich pracach poświęconych tej problematyce. Zdecydowanie preferował szkołę geografii francuskiej i to nie tylko

126 ze względu na język, którym posługiwał się biegle, lecz także dlatego, że w odróżnieniu od geografii anglosaskiej i amerykańskiej, pozostała ona najbardziej wierna klasycznemu wzorcowi badań geograficznych.

\section{Koncepcja geografii regionalnej prof. Ludwika Straszewicza}

Koncepcja regionalna profesora Ludwika Straszewicza wpisuje się częściowo w klasyczny model uprawiania geografii, zmodyfikowany przez jego indywidualne widzenie świata, ukształtowane jeszcze w okresie studiów ekonomicznych i w czasie podjętej bezpośrednio po studiach pracy $\mathrm{w}$ planowaniu regionalnym, późniejszym zaangażowaniu $\mathrm{w}$ tworzenie i uprawianie tzw. "geografii stosowanej" oraz przez czas, w którym przyszło mu działać, wyznaczony specyficznymi stosunkami społeczno-politycznymi.

Uprawiając geografię regionalna, profesor wypracował swoją metodę i sposób opisu, odnosząc je do różnych (w znaczeniu przestrzennym i przedmiotowym) obszarów badań. Stosował takie samo podejście, gdy pisał o jakimś kraju lub regionie (Straszewicz 1972a; Straszewicz 1962b), gdy przedmiotem jego badań było miasto (Straszewicz 1980b; Straszewicz 1965a) albo przemysł jako dziedzina działań ludzkich w określonym 
miejscu (Straszewicz 1961; Straszewicz 1965c). W opisie, dzięki dużym zdolnościom literackim, wykorzystywał całe bogactwo języka polskiego oraz czerpał z wiedzy nagromadzonej przez inne dyscypliny naukowe, zwłaszcza historię i ekonomię, które były mu szczególnie bliskie.

W swojej metodzie analizy wykorzystywał w pełni zasady podejścia naukowego, charakterystyczne dla klasycznego wzorca uprawiania geografii, realizując kolejne etapy postępowania badawczego.

Pierwszym z nich były wstępne, solidne, studia literaturowe, które pozwalały na zdobycie istniejącej już wiedzy o przedmiocie badania, ale również umożliwiały precyzyjne ustalenie nowego zakresu prowadzonych studiów oraz potrzebnych do ich zrealizowania źródeł pozyskania oryginalnych materiałów. Doskonałe poznanie literatury przedmiotu było konieczne, także do przeprowadzenia drugiej fazy badań, jakimi były własne studia terenowe.

Profesor uważał - wzorem klasyków geografii-że podstawą i zarazem siłą geografii, dającą jej przewagę nad innymi pokrewnymi dyscyplinami przyrodniczymi i społeczno-ekonomicznymi, są studia terenowe, polegające na poznaniu z autopsji obiektu badania. Sądził, że upowszechniająca się w jego czasach i zdobywająca coraz więcej zwolenników, związana z rewolucją ilościową tzw. "geografia zabiurkowa" stanowi zagrożenie dla geografii, ponieważ zaprzecza jej naczelnej idei, polegającej na wyprowadzaniu wniosków i uogólnień przede wszystkim z bezpośredniej obserwacji zjawisk i procesów. Rezygnacja z bezpośredniego poznania zmysłowego prowadzi do utraty specyficznego pola widzenia, związanego z tym, co Wacław Nałkowski nazywał „zmysłem geograficznym”, niezbędnego dla opisu i wyjaśnienia istoty miejsc, obszarów i zjawisk ${ }^{1}$. Geografia pozbawiona tego narzędzia poznania przestaje być równocześnie nauką holistyczną i syntetyzującą. Upodobniając się do innych dyscyplin społeczno-gospodarczych i przyrodniczych, tracąc specyfikę swojej podmiotowości przestaje być nauką potrzebną człowiekowi do zrozumienia otaczającej go rzeczywistości.

Podstawowym narzędziem stosownym w studiach terenowych była bezpośrednia obserwacja stosunków i relacji zachodzących na danym obszarze (miejscu) między poszczególnymi materialnym komponentami

${ }^{1}$ Pamiętam, jak w latach 70., pisząc doktorat z funkcji miast w regionie łódzkim, byłem zafascynowany magią metod statystycznych, które, jak wówczas uważałem, wystarczą mi w zupełności do realizacji tematu. Promotorem tej pracy był profesor Ludwik Straszewicz, który zachęcił mnie do zobaczenia wszystkich miast i zapoznania się nie tylko $\mathrm{z}$ ich tkanką materialną, ale również ze specyficzną atmosferą społeczna, charakterystyczną dla każdego z nich, np. inną w miastach małych rolniczych niż miastach małych przemysłowych. Była to doskonała lekcja, dzięki której nauczyłem się m.in. czym podejście geograficzne różni się od ujęć innych nauk. 
środowiska a mieszkańcami oraz wyczuwanie atmosfery tych miejsc, którą tworzyli żyjący w nich ludzie. Ten proces poznawczy miejsc czy regionów odbywał się przez identyfikację funkcjonowania różnych sfer gospodarki $\mathrm{w}$ drodze poznania roli działających tam instytucji społeczno-gospodarczych oraz przez bezpośrednie rozmowy i swobodne wywiady z mieszkańcami. Te ostatnie pozwalały dostrzec ich główne problemy, warunki w jakich żyli, a także satysfakcję i zadowolenie z miejsca, w którym żyją. Badaniom tym sprzyjała znajomość języków obcych (bardzo dobra francuskiego, dobra angielskiego i słabsza rosyjskiego oraz niemieckiego), pozwalająca profesorowi na osobiste kontakty z mieszkańcami i rozumienie ich sfery informacyjno-symbolicznej. Poczynione obserwacje bezpośrednie, odczucia osobiste związane $z$ przebywaniem $w$ tych miejscach oraz swobodne wywiady i rozmowy $\mathrm{z}$ ich mieszkańcami, utrwalone $\mathrm{w}$ postaci notatek i zapisów, wraz z zebraną na miejscu z odpowiednich instytucji dokumentacją stanowiły najważniejszy materiał, na którym oparte były opisy geograficzne regionów i miejsc.

Opis geograficzny, składający się z tekstu pisanego oraz zintegrowanych z nim map, tabel, wykresów i często zdjęć, stanowił ostatni etap badania regionalnego. Spełniał wiele funkcji, przysługujących podejściu regionalnemu, w znacznym stopniu podporządkowanemu klasycznemu modelowi uprawiania geografii, ale nie był on $\mathrm{z}$ nim $\mathrm{w}$ pełni tożsamy. Sam opis przyjmował charakter monograficzny, najlepiej odpowiadający istocie geografii regionalnej jako dyscyplinie traktującej obszar w jego całościowej postaci. W ujęciu profesora L. Straszewicza, w ramach rozpatrywanego problemu (społeczno-gospodarczego, przemysłowego, rolniczego czy miejskiego), odnoszącego się do miejsca czy regionu, stanowił on jednak bardziej opis jednostkowy, zajmujący się poszczególnymi warstwami życia społeczno-gospodarczego niż opis całościowy (holistyczny). Uwzględniał poszczególne komponenty środowiska materialnego obszaru, zgrupowane według ich charakteru: przyrodniczego i gospodarczego oraz wyróżnianych cech środowiska społecznego, bardzo często poprzedzonych usytuowaniem obszaru w szerszym kontekście administracyjno-politycznym oraz dziedzictwie form zagospodarowania. Modelowa struktura tego opisu przyjmowała charakter faktograficzny, w mniejszym stopniu korelacyjny, co prowadziło do ujęcia problemu badawczego raczej w formie sumy zjawisk i procesów, a nie w sposób relacyjny i holistyczny.

Opis ten miał jednak charakter syntetyzujący, przez co należy przede wszystkim rozumieć, że dotyczył on najważniejszych, najistotniejszych dla danego regionu faktów, zjawisk i procesów, wybranych ze względu na funkcjonowanie całości. Stanowiły one o odrębności lub indywidualności badanego obszaru. W mniejszym stopniu opis ten wskazywał na powiązania i uwarunkowania poszczególnych komponentów materialnych, tworzących region oraz ich związki z żyjącymi i działającymi tam mieszkańcami. 
Koncepcja regionalna profesora Ludwika Straszewicza stanowi próbę pogodzenia klasycznych ujęć regionalnych z dominującym w tym czasie branżowym modelem geografii, realizowanym zgodnie z pozytywistycznym wzorcem uprawiania nauki. Jest to szczególnie widoczne $\mathrm{w}$ strukturze prac regionalnych profesora, $\mathrm{w}$ mniejszym stopniu zaś - $\mathrm{w}$ przekazywanych treściach, które hołdują opisowi nacechowanemu nie tylko piękną forma, lecz także doskonalone rozwiniętym zmysłem obserwacyjnym profesora.

\section{Literatura}

Chojnicki Z. (1999), Podstawowe problemy filozoficzne metodologiczne przestrzeni i czasu, [w:] Z. Chojnicki (red.) Podstawy metodologiczne i teoretyczne geografii, Bogucki Wyd. Naukowe, Poznań, s. 167-174.

Kostrowicki A. S. (1997), Przestrzeń - jej istota i zróżnicowanie, „Rzeki”, t. 6, s. 125-139.

Liszewski S. [red.] (1997), Sylwetki łódzkich uczonych. Profesor Ludwik Straszewicz, z. 41, Wyd. Łódzkiego Towarzystwa Naukowego, Łódź.

Liszewski S. [red.] (2009), Łódzka szkoła geografii społeczno-ekonomicznej. Dyskusja wokół sylwetki mistrza - profesora Ludwika Straszewicza, Wyd. Łódzkiego Towarzystwa Naukowego, Łódź.

Nowakowski S. (1934), Geografia jako nauka i dzieje odkryć geograficznych, [w:] Wielka Geografia Powszechna, Wyd. Trzaska, Evert, Michalski, Warszawa.

Suliborski A. (2003), Region w syntezie i edukacji geograficznej, [w:] E. Orłowska J. Klementowski (red.), Kulturowy aspekt badań geograficznych. Studia teoretyczne i regionalne, Oddział Wrocławski PTG, Instytut Geografii i Rozwoju Regionalnego Uniwersytetu Wrocławskiego, Wrocław, s. 51-63.

Suliborski A. (2006), Geografia regionalna i jej znaczenie dla istoty geografii, [w:] A. Kostrzewski (red.), Geografia regionalna jako przedmiot badań i nauczania, Bogucki Wyd. Naukowe, Poznań, s. 15-27.

Suliborski A. (2008), O znaczeniu syntezy naukowej w geografii, [w:] S. Liszewski, J. Łoboda, W. Maik (red.), Stan i perspektywy rozwoju geografii w Polsce, KNG PAN, Wyd. Wyższej Szkoły Gospodarki, Bydgoszcz, s. 79-90.

Straszewicz L. (1954), Strefa podmiejska Łodzi, „Przegląd Geograficzny”, t. 26, z. 4, s. 182-197.

Straszewicz L. (1955), Strefa podmiejska jako problem urbanistyczny, "Miasto”, R. 6, nr 12(62), s. $29-30$.

Straszewicz L. (1956), Województwo opolskie. Zarys geografii gospodarczej, Warszawa.

Straszewicz L. (1961), Bułgarski przemyst włókienniczy, „Przegląd Geograficzny”, t. 33, z. 4, s. 663-678.

Straszewicz L. (1962a), Atlas województwa opolskiego, PPWK, Warszawa, map 16 + tekst 4 s.

Straszewicz L. (1962b), Ślask Opolski. Zarys geografii gospodarczej, Katowice.

Straszewicz L. (1963), Aglomeracja Paryża, „Przegląd Geograficzny”, t. 35, z. 4, s. 591-614.

Straszewicz L. (1965a), Aglomeracja Londynu, „Przegląd Geograficzny”, t. 37, z. 1, s. 3-28.

Straszewicz L. (1965b), Atlas województwa tódzkiego, PPWK, Warszawa, map $24+$ tekst $4 \mathrm{~s}$.

Straszewicz L. (1965c), Francuski przemyst samochodowy, „Czasopismo Geograficzne”, t. 36, z. 3, s. 301-303. 
Straszewicz L. (1966), Aglomeracja Berlina, „Przegląd Geograficzny”, t. 38, z. 1, s. 77-105.

Straszewicz L. (1967), Województwo łódzkie. Zarys geograficzno-ekonomiczny, Warszawa.

Straszewicz L. (1969a), Aglomeracja Moskwy, „Przegląd Geograficzny”, t. 41, z. 2, s. 179-210

Straszewicz L. (1969b), Rzym jako wielka metropolia świata, „Przegląd Geograficzny”, t. 41, z. 4, s. 623-650.

Straszewicz L. (1972a), Francja, Warszawa.

Straszewicz L. (1972b), Wielkie stolice Europy, Warszawa.

Straszewicz L. (1973), Atlas województwa bydgoskiego, Wyd. Geologiczne, Warszawa, map $32+$ tekst $5 \mathrm{~s}$.

Straszewicz L. (1974, 1979), Geografia ekonomiczna krajów socjalistycznych, wyd. 1, Warszawa; wyd. 2. uzup., Warszawa.

Straszewicz L. (1977), Włochy, Warszawa.

Straszewicz L. (1980a), Lizbona, „Przegląd Geograficzny”, t. 52, z. 4, s. 743-759.

Straszewicz L. (1980b), Strefa podmiejska. Pojęcia i definicje, [w:] Pojęcia i metody badań strefy podmiejskiej. Materiaty konferencyjne, Wyd. Uniwersytetu Łódzkiego, Łódź, s. 1-17.

Wilczyński W. (1996), Idea przyrody w historii myśli geograficznej, Wyd. „Jedność”, Kielce.

Andrzej Suliborski, prof. dr hab., Katedra Geografii Regionalnej i Społecznej, Wydział Nauk Geograficznych, Uniwersytet Łódzki 